\title{
WORKING BY THE LIGHT OF THE MOON: THE TRANSLATION OF 'MOONLIGHTING' IN MULTILINGUAL OFFICIAL DOCUMENTS. A REVIEW.
}

\author{
Pietro MANZELLA, Ph.D. \\ Association for International and Comparative Studies in the \\ field of Labour Law and Industrial Relations \\ Via Garibaldi 7, 24122, Bergamo, Italy \\ pietro.manzella@adapt.it
}

ORCID: https://orcid.org/0000-0001-8785-1825

\begin{abstract}
This paper examines the notion of 'moonlighting', which in industrial relations discourse refers to secondary employment performed in addition to the employee's main job. As this concept might lend itself to different interpretations in English, the aim of this paper is to consider whether the ambiguous nature of this wording in source texts is also reflected in target texts, exploring how translators deal with it when rendering this concept in other languages. To this end, documents published by international institutions in English and their translations in French, Italian and Spanish were compared and contrasted, investigating the strategies put in place by translators to convey the meaning of "moonlighting" in other languages.
\end{abstract}


Pietro Manzella: Working by the Light of the Moon...

Key words: moonlighting; translation; terminology; English; industrial relations; metaphor.

\title{
PRACUJĄC W ŚWIETLE KSIĘŻYCA: TLUMACZENIE TERMINU „MOONLIGHTING” W DOKUMENTACH WIELOJĘZYCZNYCH. \\ PRZEGLĄD.
}

\begin{abstract}
Abstrakt: Artykuł analizuje pojęcie „moonlighting”, które w dyskursie o stosunkach pomiędzy pracodawcą i pracownikami odnosi się do dodatkowego zatrudnienia wykonywanego poza główną pracą pracownika. Ponieważ koncepcja ta może podlegać różnym interpretacjom w języku angielskim, celem tego artykułu jest rozważenie, czy dwuznaczny charakter tego sformułowania $\mathrm{w}$ tekstach źródłowych znajduje również odzwierciedlenie $w$ tekstach docelowych, badając, w jaki sposób thumacze radzą sobie $\mathrm{z}$ tym przekładając to pojęcie na inne języki. W tym celu dokumenty opublikowane przez instytucje międzynarodowe w języku angielskim oraz ich tłumaczenia na francuski, włoski i hiszpański zostały porównane i skontrastowane, badając przy tym strategie stosowane przez thumaczy tak, aby oddać znaczenie „moonlighting” w innych językach.
\end{abstract}

Stowa klucze: moonlighting; thumaczenie; terminologia; język angielski; stosunki pomiędzy pracodawcą i pracownikami; metafora.

\section{Introductory Remarks}

The need for higher remuneration, the willingness to develop skills and the desire to take on more enjoyable tasks are only some of the reasons employees hold side jobs (Employers Association Forum 2018). Taking up secondary employment is often referred to as 'moonlighting', a term that has been used to denote the practice of working one or more jobs outside normal working hours. Workers engaged in moonlighting have been the focus of extensive research in the field of employee relations, which has placed emphasis on aspects like employee health and safety and the compatibility of second jobs with the one constituting the main source of income. Arguably, the intense competition for securing stable employment - coupled with salary stagnation resulting from the economic recession - has caused the number of moonlighters to escalate, especially in some sectors (UpWork 2016). 
In addition to the foregoing issues, the notion of 'moonlighting' also poses interpretative challenges, for it can designate different forms of employment. This ambiguity is due to the fact that in English-speaking countries, this terminology is loosely employed to refer to any kind of second job. In some cases, taking up a side job means engaging in illicit work; in other cases, moonlighting is simply used to indicate an additional, if legal, job (Beliveau Law Group 2018).

Consequently, the lack of clarity when using this terminology may give rise to issues resulting from the different interpretations attributed to its meaning. Problems are further compounded in translation, specifically when attempts are made to render this concept in other languages.

In view of the above, this paper examines the ambivalent nature of this wording in English and the consequences of this equivocation when 'moonlighting' is translated into other languages. The focus will be on the translation issues resulting from the ambiguous nature of this expression, considering to what extent the texts translated into the languages surveyed - namely French, Italian and Spanish - are affected by the twofold meaning taken on by moonlighting. To pursue this objective, an analysis will be carried out on a dataset consisting of documents translated into the languages referred to above, to cast light on the way 'moonlighting' has been rendered. After a review of the literature (Section 2), some definitions will be provided helping us to frame the research properly (Section 3 ). This will be followed by a reference to the methodology used (Section 4) and a discussion of the dataset created (Section 5). A concluding section will summarise the findings of this paper, putting forward some recommendations for future research (Section 6).

\section{Theoretical Background}

The concept of 'moonlighting' and its definitions in a number of languages have been the subject of extensive research in the field of employee relations and labour law. In particular, Renooy, Ivarson, Wusten-Gritsay and Meijer point out that: 


\title{
Pietro Manzella: Working by the Light of the Moon...
}

\begin{abstract}
a wide array of colourful names has been used to describe the phenomenon [...] informal economy, hidden economy, cash economy, moonlight, twilight, dual, subterranean, parallel, underground, second, unofficial and shadow economy. Similar names are found in different languages. Unfortunately, nearly as many varying descriptions of the phenomenon can be found in the literature (Renooy, Ivarson, WustenGritsay and Meijer 2004: 24).
\end{abstract}

Moreover, Russo, Fronteira, Silva Jesus and Buchan, referring to moonlighting to denote legal forms of employment, have pointed out that in documents in English, French, Portuguese, Italian, and Spanish: "alternative labels for dual practice included 'moonlighting', 'public-private work', 'multiple profit-generating activities', 'dual/multiple job-holding', and 'second jobs"” (Russo, Fronteira, Silva Jesus and Buchan 2018, online version).

Attention has also been paid to the problems posed by the translation of this term into and from English. Manzella (2015) has examined the use of this expression in EU documents, comparing the English and the Italian version of the same documents. It was found that moonlighting does not always take on a negative connotation in English, nor does it necessarily indicate undeclared work. At times, moonlighters are just multiple jobholders, so this terminology should be used carefully, for example when translating the Italian lavoro nero (undeclared work) into English (Manzella 2015). In addition, the case of moonlighting is illustrative of how opting for one word or another may affect the target audience's perception, conveying a different idea than the original one (Manzella 2019). Jamison (2018) has analysed the Spanish terminology used to denote this practice, in an attempt to explore its literal and metaphorical meaning (Jamison 2018). Lorenzo (1996) has investigated the frequency of a number of Spanish terms to translate the notion of 'moonlighting' and the usage of the latter in the Spanish language through borrowing (Lorenzo 1996).

The French translation of 'moonlighting' has also been discussed by Selva, Issac, Chanier, Fouqueré, whose research has focused above all on lexical variations and collocations (Selva, Issac, Chanier, and Fouqueré 1997). Breheret (2001) too has considered this terminology, looking at the notion of 'moonlighting' as described by the International Labour Organisation (ILO) and comparing it with the French translation in the ILO Thesaurus. As for other languages which go beyond the scope of this paper but are likewise useful to take cognizance of the ongoing debate on this topic - it has been 
argued that the word employed in Japanese to refer to this concept is arubaito, which in turn comes from the German Arbeit, meaning work. This word means part-time or temporary work or moonlighting, but it can also denote employees working regular, full hours (Mitsubishi 2013), further confirming the ambiguity of this term. In a similar vein, Molony has maintained that in some languages, e.g. Tagalog, the words used to translate the notion of moonlighting mean both 'extra job' and 'extramarital affair' thus hinting at the secretive nature of this form of employment (Molony 1978). Research has also examined the notion of 'moonlighting' and its metaphorical meaning, assessing whether this can be conveyed in other languages. In this sense, De Mooij (2014) has considered metaphors associated with the light of the moon, pointing out a number of culture-specific differences between languages. Comparing Egyptian and English cultural norms, he makes the following point:

\begin{abstract}
Expressions of culture are particularly recognizable in the use of metaphors [...] In Egypt the sun is perceived as cruel, so a girl will never be described as 'my sunshine' but may be compared with moonlight. 'Moonlight' in English means having a second job in the evening (De Mooij 2014: 46).
\end{abstract}

Silaški has also looked into this topic, stressing that in order for the metaphorical meaning of 'moonlighting' to be understandable in the target language, the metaphor has to be 'culturally determined' (Silaški 2013: 10). Finally, speaking of the Chinese market in the 1990s, Jin and Cortazzi (2011) have shown how metaphors at the time reflected a sluggish economy, so that the Chinese word employed to refer to the practice of 'moonlighting' meant both 'night' and 'a dish of food' in Chinese (Jin and Cortazzi 2011).

\title{
3. Definition, Origins of the Term, and Methodology
}

As noted above, 'moonlighting' refers to holding more than one job. The online version of the Oxford Dictionary defines it as follows: "to have a second job, typically secretly and at night, in addition to one's regular employment" (Oxford Dictionary 2019, online version). As one might infer, this terminology is metaphorical in that it denotes 
work "conducted 'under the light of the moon', meaning that it is performed at night with or without the knowledge of one's primary employment" (Collins 2018: 432). The origins and evolution of the term are also fascinating, because they are illustrative of how it retained certain ambiguity in relation to its usage. At first, it was a slang term for the activity of burglars, who benefitted from the moonlight to engage in their criminal activities, while in the twentieth century it was also used in connection with herding cattle and hunting deer by moonlight (Metcalf 2002).

Significantly "whether it was illegal work that in 1957 caused the transmutation of moonlight into a standard term for legal work, or whether this new meaning was independently derived from the original moonlight, nobody knows" (Metcalf 2002: 4). What is certain is that today this expression lends itself to different interpretations. At times, moonlighting is used in English to refer to undeclared work. For instance, referring to the shadow economy, Enste (2005) argues that "one has to distinguish between goods and services produced and consumed within the household, soft forms of illicit work (moonlighting), illegal employment and social fraud" (Enste 2005: 114). In other cases, moonlighting does not entail engaging in illegal activities. Discussing the case of the US, Guerin has argued that "some states have passed off-duty conduct laws protecting employees from discrimination based on what they do on their own time" (Guerin 2011: 207). The ambiguous nature of moonlighting is also evident at the institutional level. By way of example, the ILO's definition seems to brook no argument, defining 'moonlighting' as the situation in which "a person, in addition to his or her regular employment, carries out work for payment illegally or undeclared for tax purposes" (ILO 2003). Conversely, the Glossary of the US Department of Labor considers the term to denote "working more than one job" (US Department of Labor 2019, online version).

In relation to methodology, this paper sets out to assess how this term is used when employed in translations from English into other languages. The aim was to evaluate whether using this term results in ambiguity and a lack of equivalence between the source and the target text. In order to investigate this question, a dataset was created consisting of 90 documents discussing the practice of holding multiple jobs. This dataset included original texts, i.e. produced in a source language, and their translation into the languages surveyed (Neubert 2010). The dataset was made up as follows: 30 texts 
produced in English and then translated into French; 30 documents written in English and then rendered in Italian; 30 texts drafted in English and then translated into Spanish. These languages were chosen on the basis of the proficiency of the author in the three languages.

The documentation under examination were informative materials (Cao 2007) published by international institutions operating in different languages, namely the ILO, the European Foundation for the Improvement of Living and Working Conditions (EUROFOUND), and the OECD, manually identifying those discussing the issue of multiple jobholding. The texts drafted in English were then contrasted with their translations, comparing the strings where reference was made in both texts to the notion of moonlighting. When selecting the documents, the date of publication was not considered, as this criterion seems of no consequence for the purpose of this paper. In the next section, a description will be provided of the meaning assigned to 'moonlighting' in each article and in each language, discussing whether or not there was a move away from source-text meaning.

4. Data Analysis and Discussion

\section{a) Moonlighting in French}

Table 1 outlines the terminology used in French to refer to 'moonlighting' in the translated texts:

Table 1. Words used in French documents to translate 'moonlighting' (by frequency)

\begin{tabular}{|c|c|}
\hline French Terminology & Frequency \\
\hline Travail au noir & 11 \\
\hline Cumul d'emplois & 8 \\
\hline Travail clandestine & 6 \\
\hline Double casquette & 5 \\
\hline
\end{tabular}

Source: Own elaboration on the dataset created by the author (2019). 
Most documents translated into French refer to the notion of 'moonlighting' using the expression travail au noir ('working in the black economy' in English). It might be interesting to note that the use of this expression constitutes an attempt to convey the metaphorical meaning of the expression used in the source text. As we have seen, 'moonlighting' in English implies that work is performed secretly i.e. at night, surreptitiously - and is well established in Anglo-Saxon discourse.

Conversely, doubts may be cast as to whether travail au noir performs the same function in French (but the same question can be raised in relation to Spanish and Italian, as will be explained further on in this paper). On close inspection, this expression may simply refer to working night shifts, without this working arrangement necessarily being related to having two jobs or being engaged in illegal work. Consequently, the metaphorical meaning of 'moonlighting' seems to be lost in translation. This brings to mind the work of Dunn when examining the difficulties resulting from dealing with metaphor in industrial relations discourse, in that "metaphor, though useful, is dangerous" (Dunn 1990: 2). Alternatively, cumul d'emplois has been employed to translate the expression into French. This refers to the concept of multiple job holding and does not take on a negative connotation, so target-text readers may be led to believe that the work is carried out above board. On balance, specifying the contours of the work taken up would make this aspect clearer.

In a number of cases, travail clandestin was also employed, which means 'undeclared work' in English. In this context clandestin does not correspond exactly to the English 'clandestine', which might also mean 'secretly' and thus could also refer to work performed not necessarily illicitly. In French, clandestin carries a connotation of illegality, thus leading readers of French texts to assume that the work referred to in the documents translated violates the law. In this sense, the Cambridge French-English Dictionary defines this adjective as follows: "qui se fait de manière secrète et contraire à la loi" (Cambridge 2019, our translation: "done secretly and against the law").

A passing reference should also be made to an idiomatic expression, which at times has been used to translate moonlighting into French, namely avoir une double casquette. While employed in a limited number of documents, this wording is worth a mention for it constitutes an attempt to convey the meaning of the source text by 
means of a metaphor that can be fully understood by the source-text audience. Avoir une double casquette literally means 'to wear two hats' but, when used figuratively, it has the same meaning as 'moonlighting'. Arguably, different metaphors can be used in different languages to express the same concept, a point investigated in Lakoff and Johnson's seminal work (Lakoff and Johnson 1980).

\section{b) Moonlighting in Italian}

Table 2 shows the Italian terminology used to refer to 'moonlighting':

Table 2. Words used in Italian documents to translate 'moonlighting' (by frequency)

\begin{tabular}{|c|c|}
\hline Italian Terminology & Frequency \\
\hline Doppio lavoro & 15 \\
\hline Secondo lavoro & 10 \\
\hline Lavoro nero & 5 \\
\hline
\end{tabular}

Source: Own elaboration on the dataset created by the author (2019).

Examining the texts drafted in English and subsequently translated into Italian, moonlighting has been mostly rendered with the expression doppio lavoro ('having two jobs' in English). This wording generally refers to taking on two jobs simultaneously, although it does not hint at one of them being illegal. Nevertheless, there is one point that should be stressed when considering this expression, for "words, especially when they undergo translation, are not always what they seem" (Hyman 2001: 38).

Though doppio lavoro does not immediately bring to mind undeclared work, most texts investigated where this expression was used discuss the issue of holding multiple jobs in the public sector, which is prohibited in Italy in most cases. In consequence, when dealing with public-sector employment, doppio lavoro clearly takes on a negative connotation. In this set of documents, the translator should have stressed this aspect more clearly, in order to highlight the illicit character of this form of employment. However, the context makes it clear that 'moonlighting' denotes undeclared work.

It is evident that the contextual dimension plays a key role in translation. Echoing Newman (1991) and more recent research (Saldanha and O'Brien 2013; Schoonjans 2015; Bassnett 2013), there 
is overwhelming agreement that words only "acquire their full semantic and pragmatic meaning when they are used in a particular context" (Schoonjans 2015: 3). Yet a periphrasis (e.g. 'illegal or undeclared work') would have been provided a better picture of the concept at issue, underlining the fact that this way of working is against the rules.

Secondo lavoro ('second job' in English) is the other locution that is frequently adopted to translate moonlighting into Italian. The meaning is similar to that of doppio lavoro, although perhaps secondo in Italian conveys the idea that this employment is of less importance than the one regarded as the 'first' or 'primary'. It seems as though the job providing the main source of income and the second job were not placed on an equal footing. This nuanced meaning appears to be nicely expressed by 'moonlighting' which, by definition, is work performed in addition to the day job. As far as the legal/illegal dichotomy is concerned, secondo lavoro is as neutral as doppio lavoro, although in the data examined secondo lavoro is used more often to refer to legal activities. It is important to point out that nuances of meaning should not be lost in translation, in an awareness that "there comes a point when words leap out of their conventional boundaries and embrace different shades of meaning" (Kothari 2003: $1)$.

Finally, albeit to a lesser extent, lavoro nero ('undeclared work') is also used to translate 'moonlighting' into Italian. Evidently, this expression in Italian allows for no ambiguity whatsoever, in that it clearly denotes work performed illegally. The wording in the target text plainly defines the nature of employment, leaving little room for interpretation.

\section{c) Moonlighting in Spanish}

Table 3 shows the Spanish terminology employed to refer to 'moonlighting'.

Table 3. Words used in Spanish documents to translate 'moonlighting' (by frequency)

\begin{tabular}{|c|c|}
\hline Spanish terminology & Frequency \\
\hline Pluriempleo & 17 \\
\hline Segundo empleo & 13 \\
\hline
\end{tabular}


Source: Own elaboration on the dataset created by the author (2019).

The texts produced in Spanish that were surveyed for this research contain two expressions for 'moonlighting', namely pluriempleo and segundo empleo. Apparently, it seems that neither of these terms denotes the illegal nature of this form of employment, giving the impression that people engaged in pluriempleo or a segundo empleo do not infringe the rules. Pluriempleo can be translated into English as 'multiple job holding', thus this expression does not appear to have a negative connotation nor to make any reference to undeclared work. In principle, this is true. However, pluriempleo is not as innocent as it seems, as it can also refer to illegal work. In this sense, the ILO defines pluriempleo as follows: "Situación en que una persona realiza, además de su trabajo regular, otro ilegal o no declarado" (ILO, 2003, Our translation: "a situation in which a person engages in illegal or undeclared employment, in addition to his/her regular job"). Consequently, although widely employed to refer to legal forms of work, one should be aware that in some specialised settings this terminology can also take on a negative connotation. This is further confirmation of the difficulties arising from translating words when engaging in comparative research. As recalled by Schregle:

\footnotetext{
Concepts, expressed in words, are laden with values, emotions, past experiences, and future expectations. Extracting such words from their national context and translating them into what appears to be the equivalent in another language, i.e. another society, is a difficult exercise indeed (Schregle 1981: 25)
}

This is true considering that the ILO provides a number of synonyms for pluriempleo, namely empleo doble ('dual employment' in English), but above all empleo informal and empleo oculto ('informal work' and 'undeclared work' in English, respectively), supporting the argument that pluriempleo can define both illegal and legal forms of employment.

As for segundo empleo, it simply refers to the practice of having another job besides the one that provides an individual's main source of income. As argued in the case of the Italian secondo lavoro, the meaning of which is similar to segundo empleo, in Spanish this terms constitutes neutral terminology and is not associated with illegal work. Accordingly, 'moonlighting' might be problematic for target 
text readers, as they might be left wondering whether reference is made to licit or illicit work.

Specifying the nature of the side job taken up by workers might help to dispel doubts and make sense of the type of work discussed.

It should be pointed out that not once was the Spanish pulpear used in the texts under examination, the correspondence of which with 'moonlighting' would have been interesting to examine. Pulpear literally means 'to move like an octopus' (pulpo is the Spanish for octopus) but, figuratively, it also refers to "working extra odd jobs or to moonlight to make a living" (Jamison 2018: 30). The fact that none of the documents examined contained the word in question might be due to the fact that this expression is mainly used in Panama (Jamison 2018).

\section{Conclusions}

The present paper examined the notion of 'moonlighting' and the ways it was rendered in French, Italian and Spanish in documents published by international institutions for informative purposes. The issue bears relevance in that in Anglo-American employment relations discourse, this terminology retains some degree of ambiguity, i.e. it could refer to illegal or legal forms of employment. The analysis of the documents produced different outcomes, depending on the language under consideration. Starting with French, translators resorted to several strategies to translate the concept, resulting in distinct outcomes as far as the source-text meaning is concerned. In some cases, the terminology adopted appears to be too generic, due to a lack of equivalence with the source text. One reason for this is that the language used in the target texts failed to convey one or more meanings associated with the terms in the original. Such is the case of travail au noir, which can simply be used to refer to working at night, without indicating whether the work performed is legal or not. In other cases, translators chose to take a clearer stance and to convey one meaning (e.g. the fact of working multiple jobs, with cumul d'emplois) or the other (e.g. the illicit nature of work, with travail clandestin). Interestingly enough, in only a limited number of cases 
did the translator seek to find the equivalent metaphor in the target text that could adequately convey the figurative meaning of the source text (that is the case of la double casquette). Taking into account all the languages examined, this is the only attempt to render a metaphor through another metaphor. In all other instances, translators sought to express the meaning without resorting to metaphor. The Italian doppio lavoro and secondo lavoro are illustrative in this sense, as the stress is placed on the numerical dimension rather than on the legal/illegal dichotomy, although this emphasises that less importance is given to this form of employment relative to the primary one. The alternative in a number of texts, lavoro nero, has a clear-cut meaning and implies that the work is carried out illicitly. Finally, Spanish translators made recourse to just two expressions to render moonlighting, namely pluriempleo and segundo empleo, which both denote 'moonlighting' as an extra activity.

Three conclusions can be drawn from the above. First, as noted above, different strategies were put in place to render 'moonlighting' in the languages examined. This might appear as an obvious statement, yet what is striking is the fact that only French translators attempted to find a metaphor conveying the same meaning as in the source language. It would have been interesting to determine whether this state of affairs was the result of the ambiguity of 'moonlighting' in the source language, or simply of a lack of a metaphor carrying the same meaning in the target languages where this figurative device was not used. Secondly, the documents examined, although official in character, were produced for information purposes. This partly explains the presence of 'moonlighting', which is often referred to as informal terminology (Oxford Dictionary 2019). Most translations resorted to formal expressions to render the expression, thus marking a clear difference in register between the source and the target text. Future research on this issue could address this issue, namely whether this divergence in terms of degree of formality was intentional or due to a lack of equivalent terminology in the target language.

Finally, and related to the previous points, research could also be extended to other types of text, e.g. normative texts, to examine alternative approaches to rendering the concept analysed in this paper. 
Pietro Manzella: Working by the Light of the Moon...

\section{References}

Bassnett, S. 2013. Translation Studies. Abingdon: Routledge.

Beliveau Law Group. 2018. "Employers and workers should handle 'moonlighting' with care." Accessed 12 December 2018. https://www.beliveaulaw.net/2012/05/employers-andworkers-should-handle-moonlighting-with-care/.

Breheret, J. 2001. "Le travail à 'temps partagé'. Rapport de recherche bibliographique." Accessed 12 March 2019. http://enssibal.enssib.fr/bibliotheque/documents/dessid/rrbbre heret.pdf.

Cambridge French-English Dictionary. 2019. "Clandestin.” Accessed 2

December

2018.

https://dictionary.cambridge.org/dictionary/frenchenglish/clandestin.

Cao, D. 2007. Translating Law. Clevedon: Multilingual Matters LTD.

Collins, J. M. 2018. HR Management in the Forensic Science Laboratory: A 21st Century Approach to Effective Crime Lab Leadership. London: Elsevier.

De Mooij, M. 2014. Global Marketing and Advertising: Understanding Cultural Paradoxes. Sage: Los Angeles.

Dunn, S. 1990. "Root Metaphor in the Old and New Industrial Relations." British Journal of Industrial Relations 28 (1): 132.

Employers Association Forum. 2018. "Moonlighting Employees." Accessed 10 January 2019. https://eafinc.org/employees-whomoonlight/.

Enste, D. H. 2005. "The Shadow Economy in OECD and EU Accession Countries. Empirical Evidence for the Influence of Institutions, Liberalisation, Taxation and Regulation." In Size and Consequences of the Underground Economy, edited by $\mathrm{C}$. Bajad, F. Schneider, 114-121. Abingdon: Routledge.

Guerin, L. 2011. Employment Law. The Essential HR Desk Reference. Berkeley: Nolo.

International Labour Organisation. 2003. ILO Thesaurus: Moonlight. Accessed 3 May 2019. http://ilo.multites.net/default.asp

International Labour Organisation. 2003. ILO Thesaurus: Pluriempleo. Accessed 3 May 2019. http://ilo.multites.net/default.asp 
Hyman, R. 2001. Understanding European Trade Unionism. Between Market, Class, and Society. London: Sage.

Jamison, L. 2018. Panamanian Spanish: Speak like a Native! New York: GringoGuide200.

Jin, L. \& M. Cortazzi. 2011. "Educational Metaphors in China." In Education Reform in China: Changing Concepts, Contexts and Practices, edited by J. Ryan, 113-131. Abingdon: Routledge.

Kothari, R. 2013. Translating India. The Cultural Politics of India. Abingdon: Routledge.

Lakoff, G. \& M. Johnson. 1980. Metaphors We Live By. Chicago: Chicago University Press.

Lorenzo, E. 1996. Anglicismos hispánicos. Madrid: Gregos.

Manzella, P. 2015. "Lost in Translation: Language and Cross-national Comparison in Industrial Relations". The E-Journal of International and Comparative Labour Studies. 4 (1). $\begin{array}{lllll}\text { Accessed } & \text { on } & 4 & \text { April }\end{array}$ http://ejcls.adapt.it/index.php/ejcls_adapt/article/view/260

Manzella, P. 2019. "Shades of Meaning". ITI Bulletin: The Journal of the Institute of Translation and Interpreting, January/February.

Metcalf, A. A. 2002. Protecting new Words: The Secrets of their Success. Boston: Houghton Mifflin.

Mitsubishi Corporation. 2013. Japanese Business Language. Abingdon: Routledge.

Molony, C. 1978. "Lexical Changes in Philippine Creole Spanish." In Approaches to Language: Anthropological Issues, edited by W. C. McCormack, S. Wurm, 401-417. The Hague: Mouton.

Neubert, A. 2010. "Translation Contextualised. How Electronic Text Worlds are Revolutionising the Context of Translation." In Meaning in Translation - Lodz. Studies in Languages, edited by B. Lewandowska-Tomaszczyk, M. Thelen, 305-337. Frankfurt am Main: Peter Lang.

Newmark, P. 1991. About Translation. Clevedon: Multilingual Matters.

Oxford Dictionary. 2019. "Moonlight". Accessed 3 April 2019. https://en.oxforddictionaries.com/definition/moonlight

Renooy, P., Ivarsson, S., Wusten-Gritsai, O., Meijer, R. 2004. Undeclared work in an enlarged Union. An analysis 
Pietro Manzella: Working by the Light of the Moon...

of undeclared work: an in-depth study of specific items. Brussels: European Commission.

Russo, G., Fronteira, I., Jesus, T., Buchan, J. 2018. "Understanding nurses' dual practice: A scoping review of what we know and what we still need to ask on nurses holding multiple jobs." Human Resources for Health. 16 (14). 10.1186/s12960-0180276-x.

Saldanha, G. \& S. O’Brien. 2013. Research Methodologies in Translation Studies. Abingdon: Routledge.

Schoonjans, S. 2015. "The Influence of Context on the Translation of Modal Particles." In Papers in Translation Studies, edited by S. Izwaini, 2-24. Newcastle upon Tyne: Cambridge Scholars Publishing.

Schregle, J. 1981. "Comparative Industrial Relations: Pitfalls and Potential." The International Labour Review 120 (1): 15-30.

Selva, T., Issac, F., Chanier, T., Fouqueré, C. 1997. "Lexical comprehension and production in Alexia system." Language Teaching and Language Technology. April (2).

Silaški, N. 2010. "Translating metaphorical economic terms from English into Serbian - some strategies and challenges." Accessed $11 \quad$ March 2019. https://www.researchgate.net/publication/259821157_Silaski_ N_2010_Translating_metaphorical_economic_terms_from_E nglish_into_Serbian__some_strategies_and_challenges_International_conference_P hilological_research_today__language_literature_and_communi

UpWork. 2016. "New Study Finds Freelance Economy Grew to 55 Million Americans This Year, 35\% of Total U.S. Workforce." $\begin{array}{llll}\text { Accessed } & 14 & \text { February } & \end{array}$ https://www.globenewswire.com/newsrelease/2016/10/06/992265/0/en/New-Study-Finds-FreelanceEconomy-Grew-to-55-Million-Americans-This-Year-35-ofTotal-U-S-Workforce.html

US Department of Labor. 2019. Glossary. Accessed 13 January 2019. https://www.dol.gov/general/aboutdol/history/glossary 